\title{
6"-Thioether tobramycin analogues: Towards selective targeting of bacterial membranes
}

\author{
Ido M. Herzog, Keith D. Green, Yifat Berkov-Zrihen, Mark Feldman, Roee R. Vidavski, Anat \\ Eldar-Boock, Ronit Satchi-Fainaro, Avigdor Eldar, Sylvie Garneau-Tsodikova, and Micha \\ Fridman
}

\section{Keywords}

Aminoglycosides analogues; Aminoglycoside-modifying enzymes; Bacterial resistance; Cationic amphiphiles; Hemolysis

Decades of widespread clinical use of the bacterial ribosome A-site targeting aminoglycosides (AGs) enhanced the evolution of resistance to these antibiotics and reduced their clinical efficacy. ${ }^{[1]}$ Three modes of action lead to bacterial resistance to AGs: reduction in the intracellular concentration of the antibiotics by efflux pump proteins or through reduced membrane permeability; structural modifications of the 16S ribosomal RNA leading to reduced target affinity; and deactivation by AG-modifying enzymes (AMEs). ${ }^{[1 \mathrm{c}, 2]}$ AMEs are divided into three families: AG nucleotidyltransferases (ANTs), AG phosphotransferases (APHs), and AG acetyltransferases (AACs). ${ }^{[1 b, 3]}$

In many cases, AG-resistant bacteria have evolved combinations of resistance mechanisms, a fact that greatly increases the challenge of regaining their clinical efficacy through semisynthetic modifications. In recent years, several studies demonstrated the potential of exploiting AGs for the development of cationic amphiphilic antimicrobial agents by converting part or all of their pseudo-oligosaccharide alcohols into alkyl or aryl ethers. ${ }^{4]}$ Some of these amphiphilic analogues demonstrated improved activities against several bacterial strains with resistance to the parent AG antibiotics. In addition to AG-based amphiphiles, several families of cationic amphiphiles including cationic steroids (ceragenins) ${ }^{[5]}$ as well as cationic antimicrobial peptides and peptido-mimetics ${ }^{[6]}$ have been developed and were found to possess potent antimicrobial activity. Unlike most mammalian cell membranes, bacterial membranes are rich in negatively-charged lipids such as cardiolipins and phosphatidylglycerol, which attract cationic amphiphiles through ionic interactions, ${ }^{[5]}$ a fact that may be utilized for selective targeting of bacterial membranes.

In this manuscript we report the design, synthesis, and antibacterial activity of 18 cationic amphiphiles (4a-r) derived from tobramycin (TOB) (Scheme 1A), a clinically important AG antibiotic that is becoming increasingly compromised by bacterial resistance. We also provide evidence for the mode of action of these derivatives and for the structural requirements for bacterial membranes targeting compared to membranes of red blood cells (RBCs).

We chose to modify the 6"-primary alcohol of TOB and focused on two groups of lypophilic substituents: (i) aliphatic moieties including linear alkyl chains ranging from 6 to 22 carbons in length as well as branched and cyclic alkyls, and (ii) substituted aryl rings. The five amine groups of TOB were protected by Boc groups and the 6"-primary alcohol was selectively converted to the corresponding $O$-trisyl leaving group to provide compound $\mathbf{2}$ as previously reported (Scheme 1A). ${ }^{[7]}$ Compound 2 was then reacted with each of the 18 aliphatic and 
aromatic thiols resulting with the Boc-protected compounds 3a-r in yields ranging from 57 to $94 \%$. Removal of all Boc protecting groups in neat TFA gave the TFA salts of the 6"thioether TOB derivatives $\mathbf{4 a - r}$ with no need for further purification in yields ranging from 74 to $98 \%$.

Compounds 4a-r were screened for their antibacterial activity against 21 Gram-positive and Gram-negative bacterial strains and their minimum inhibitory concentrations (MICs) were determined (Table 1). Amongst the Gram-positive bacteria were pathogenic strains such as methicillin-resistant Staphylococcus aureus (MRSA) (strain C) and vancomycin-resistant Enterococcus (VRE) (strain $\mathbf{J}$ ) that displayed high levels of resistance to TOB (MIC $\geq 150$ $\mu \mathrm{g} / \mathrm{mL}$ ). Amongst the Gram-negative were 3 strains of E. coli BL21 (DE3) that we cloned with AMEs: the bi-functional AAC(6')/APH(2"), AAC(3)-IV, and the multi-acetylating Eis, an AAC that confers high levels of resistance to AGs in extensively-drug resistant (XDR) strains of Mycobacterium tuberculosis $(\mathbf{M t b})^{[8]}$ (strains $\mathbf{O}, \mathbf{P}$, and $\mathbf{Q}$, respectively). These three strains had significant to high levels of resistance to TOB (MICs $>150,=150$, and 18.8 $\mu \mathrm{g} / \mathrm{mL}$, respectively).

The linear aliphatic-chain analogues $\mathbf{4 a - h}$ exhibited a parabolic pattern of chain-length dependent antibacterial activity (Figure $\mathrm{S} 45 \mathrm{~A}$ ). Compared to TOB, both the $\mathrm{C}_{6^{-}}$and $\mathrm{C}_{8^{-}}$ chain analogues $4 \mathbf{a}$ and $\mathbf{4 b}$ demonstrated a dramatic loss of antibacterial activity, the $\mathrm{C}_{10^{-}}$ chain derivative $4 \mathbf{c}$ regained some activity, and the $\mathrm{C}_{12}$-chain analogue $4 \mathbf{d}$ demonstrated potent antibacterial activity against several of the strains with resistance to TOB. The greatest improvement in antibacterial activity was observed for the $\mathrm{C}_{14^{-}}$and $\mathrm{C}_{16^{-}}$-chain derivatives $\mathbf{4 e}$ and $\mathbf{4 f}$, with the most significant effect for $\mathbf{4 e}$ that showed marked activity against all of the 21 tested strains. The MIC values of $4 \mathbf{e}$ ranged between 0.3 to $18.8 \mu \mathrm{g} / \mathrm{mL}$ against 19 of the 21 tested strains: the exceptions were E. faecalis $(\mathbf{K})$ and $S$. enterica $(\mathbf{U})$ where only a limited improvement in the antibacterial activity of $\mathbf{4 e}$ as compared to TOB was observed (MIC of $4 \mathrm{e}: 75$ and $37.5 \mu \mathrm{g} / \mathrm{mL}$, respectively, and for TOB: $150 \mu \mathrm{g} / \mathrm{mL}$ ). The antibacterial activity dropped again for the $\mathrm{C}_{18^{-}}$and the $\mathrm{C}_{22}$-chain analogues $\mathbf{4 g}$ and $\mathbf{4 h}$. With few exceptions, a general drop in the antibacterial activity was observed for the 6"aromatic-thioethers $(\mathbf{4 k - r})$. The more substitution around the aryl ring, the more significant was the loss of antibacterial activity against the tested strains. For example, of the aromatic thioether analogues, $\mathbf{4 k}$ with the thiophenyl ring, and $\mathbf{4 l}$ with the 4-methyl-thiophenyl ring, demonstrated the best overall antibacterial activity against the tested strains. However, a drop in antibacterial activity was observed for the 2,6-dimethyl-thiophenyl derivative $\mathbf{4 m}$, and a more significant drop was observed for the 2,4,6-trimethyl-thiophenyl analogue $4 \mathbf{n}$. Since thioethers may be susceptible to cellular mediated $S$-oxidation, ${ }^{[9]}$ we oxidized two of the most potent thioethers $(\mathbf{4 d}-\mathbf{e})$ to diastereomeric mixtures ( $4: 1$ ratio) of the corresponding sulfoxides (5d-e) and to the sulfones (6d-e) (Scheme 1B). The effect of $S$ oxidation on the antibacterial activity varied amongst the tested bacterial strains. A reduction in the antibacterial activity of both sulfoxide and sulfone analogues as compared to the parent thioethers was observed for the E. coli BL21 (DE3) strains $\mathbf{M}-\mathbf{Q}$ and for $B$. subtilis 168 with $\mathrm{AAC}\left(6^{\prime}\right) / \mathrm{APH}\left(2^{\prime \prime}\right)-\mathrm{pRB} 374$ (strain G). In contrast, when tested against $E$. faecalis $(\mathbf{K})$ and $L$. monocytogenes $(\mathbf{L})$, all four $S$-oxidized analogues demonstrated improved antibacterial activities compared to that of the thioethers 4de. For most of the tested strains, $S$-oxidation did not have a dramatic effect on the antibacterial activity with MIC values identical or one double-dilution higher than those of the thioethers $4 \mathbf{d}-\mathbf{e}$. In most of the tested strains, MIC values were identical for the sulfoxides (5d-e) and the corresponding sulfones ( $\mathbf{6 d - e}$ ) indicating that the level of $S$-oxidation has little to no effect on antibacterial activity.

To uncover the reasons for the broad spectrum and improved antimicrobial activity of some of the thioether analogues, we performed several biological tests. The effect of compound $\mathbf{4 e}$ 
on the translation of a luciferase reporter gene was measured in E. coli cell lysates. In lysates of Mycobacterium smegmatis and E. coli, previous studies reported that TOB inhibited luciferase translation at $\mathrm{IC}_{50}$ values of $\sim 20 \mathrm{nM} \cdot{ }^{[10]}$ In our $E$. coli cell lysate, TOB potently inhibited translation $\left(\mathrm{IC}_{50}=8.9 \pm 1.9 \mathrm{nM}\right.$ ), whereas $4 \mathrm{e}$ did not reach $\mathrm{IC}_{50}$ value even at 147 $\mathrm{nM}$ (measured using the free base forms of TOB and 4e), suggesting that this compound does not target the bacterial ribosome as its major mode of antibacterial activity.

Furthermore, time of kill assays performed on $S$. mutans UA159 (E) and $S$. pyogenes (D) revealed that $4 \mathbf{e}$ rapidly conferred bacterial cell death as compared to TOB (Figure S45B). At MIC values $(2.3 \mu \mathrm{g} / \mathrm{mL}$ for $\mathbf{4 e}$ on both strains, and $75 \mu \mathrm{g} / \mathrm{mL}$ (S. mutans) or $18.8 \mu \mathrm{g} / \mathrm{mL}$ (S. pyogenes) for TOB) no viable bacteria remained in the sample treated with $4 \mathbf{e}$ after 5 hours of incubation with $S$. mutans and 3 hours of incubation with $S$. pyogenes. For both of these strains, almost no reduction in bacterial growth was observed for TOB after the same incubation time. The luciferase translation assay results and the rapid time of kill displayed by $\mathbf{4 e}$ suggested that this compound acts by disrupting the bacterial cell membrane. Additional strong evidence for the membrane disruption effect of $\mathbf{4} \mathbf{e}$ was obtained by fluorescence microscopy experiments (Figure 1). Fluorescently labeled B. subtilis with constitutive YFP expression (PY79) ${ }^{[11]}$ was incubated for 1 hour with $4 \mathbf{e}$ or with TOB at several concentrations. After 1 hour of incubation with TOB at both $2 \times$ and $8 \times$ the MIC $(2.3$ and $9.4 \mu \mathrm{g} / \mathrm{mL}$, respectively), most of the bacterial cells in the sample were viable and maintained good fluorescence. In contrast, a significant drop in fluorescence presumably resulting from the bacterial cell lysis and loss of intracellular content including the YFP was evident after the same incubation time with compound $4 \mathbf{e}$ at both $2 \times$ and $8 \times$ the MIC $(4.7$ and $18.8 \mu \mathrm{g} / \mathrm{mL}$, respectively).

The selectivity of the 6"-thioether derivatives $\mathbf{4 b}$-h towards bacterial membranes was tested using a hemolysis assay on both laboratory rat and human RBCs (Figure 2). The MICs of the most potent thioether analogues ranged between 0.3 to $18.8 \mu \mathrm{g} / \mathrm{mL}$. Hence, RBCs samples were incubated with analogues $\mathbf{4 d - f}$ at a concentration of $75 \mu \mathrm{g} / \mathrm{mL}$, which is 4250 times greater than the MIC range and at $18.8 \mu \mathrm{g} / \mathrm{mL}$, which is $1-60$ times the MIC range. At $75 \mu \mathrm{g} / \mathrm{mL}$, TOB as well as compounds $4 \mathbf{b}$ and $4 \mathbf{c}$ with the $\mathrm{C}_{8^{-}}$and $\mathrm{C}_{10}$-linear chains caused no measurable hemolysis of rat and human RBCs. Compound $\mathbf{4 d}$ with the $\mathrm{C}_{12}$-chain caused $12.6 \pm 0.6 \%$ hemolysis of rat RBCs and $7.9 \pm 1.7 \%$ hemolysis of human RBCs. Both compounds $\mathbf{4 e}\left(\mathrm{C}_{14}\right.$-chain) and $\mathbf{4 f}\left(\mathrm{C}_{16}\right.$-chain $)$ caused extensive hemolysis at 75 $\mu \mathrm{g} / \mathrm{mL}$ with $93.6 \pm 5.5 \%$ and $90.2 \pm 4.5 \%$ of rat RBCs, and $93.7 \pm 11.1 \%$ and $93.1 \pm 5.1 \%$ of human RBCs, respectively. Compound $\mathbf{4 g}\left(\mathrm{C}_{18}\right.$-chain) caused $77.2 \pm 7.0 \%$ hemolysis of rat RBCs and $74.3 \pm 9.0 \%$ hemolysis of human RBCs. A significant drop in the hemolytic activity was observed for compound $\mathbf{4 h}\left(\mathrm{C}_{22}\right.$-chain), $24.4 \pm 5.8 \%$ of rat $\mathrm{RBCs}$ and $7.1 \pm$ $0.1 \%$ of human RBCs.

At $18.8 \mu \mathrm{g} / \mathrm{mL}$, TOB and analogues $\mathbf{4 b}-\mathbf{d}$ with the $\mathrm{C}_{8^{-}}, \mathrm{C}_{10^{-}}$, and $\mathrm{C}_{12^{-}}$-linear chains caused no measurable hemolysis of both rat and human RBCs, and compound $4 \mathbf{e}\left(\mathrm{C}_{14}\right.$-chain) caused $19.5 \pm 0.3 \%$ hemolysis of rat RBCs and $14.3 \pm 1.7 \%$ hemolysis of human RBCs. Compound $\mathbf{4 f}\left(\mathrm{C}_{16}\right.$-chain) demonstrated the maximal hemolytic effect of $40.4 \pm 1.7 \%$ (rat $\mathrm{RBCs}$ ) and $25.4 \pm 2.1 \%$ (human $\mathrm{RBCs}$ ), while $\mathbf{4 g}\left(\mathrm{C}_{18}\right.$-chain) caused $26.3 \pm 1.9 \%$ hemolysis of rat RBCs and $8.0 \pm 0.8 \%$ hemolysis of human RBCs. At $18.8 \mu \mathrm{g} / \mathrm{mL}$ compound $\mathbf{4 h}\left(\mathrm{C}_{22^{-}}\right.$ chain) caused $4.4 \pm 0.5 \%$ hemolysis of rat RBCs and no measurable hemolysis of human RBCs. Although compound $\mathbf{4 f}$ with the $\mathrm{C}_{16}$-chain was one of the most active TOB analogues against the tested bacterial strains, it readily disrupted $\mathrm{RBC}$ membranes as well. In contrast, compound $\mathbf{4 d}\left(\mathrm{C}_{12}\right.$-chain) demonstrated potent antimicrobial activity against several of the TOB-resistant bacterial strains and caused little to no measurable hemolysis at the tested concentrations. The hemolysis assay demonstrated that the aliphatic chain length plays a key role in selective targeting of the bacterial membranes versus those of RBCs. 
Several amphiphilic AGs based on paromomycin were recently shown to act as inhibitors of the AME APH $\left(3^{\prime}\right) .{ }^{[12]}$ Moreover, amphiphilic AGs can make their way into the bacterial cell where they are exposed to enzymatic modifications by AMEs. AME modifications $(O-$ phosphorylation, $O$-adenylation, and $N$-acetylation), result in a reduction of the overall positive charge of the parent AG. Hence, AME modifications may reduce the affinity of amphiphilic AGs to the negatively-charged bacterial membrane and hamper their antimicrobial activity. Structural information obtained from crystallographic studies of several AMEs indicated that the AG binding pocket is rich in negatively-charged amino acid residues such as glutamic and aspartic acids and that several water molecules are required to stabilize the interactions between AGs and the AMEs' binding pockets. ${ }^{[13]}$ We reasoned that the replacement of the 6"-primary alcohol of TOB with hydrophobic residues would interfere with these hydrophilic-based binding interactions and reduce the ability of the enzymes to modify these molecules. To test this hypothesis, the relative activities of seven different $\mathrm{AMEs}^{[14]}$ on compounds $4 \mathbf{a}-\mathbf{r}$ were compared to that of TOB (Figure 3). While some of the modified compounds served as better substrates for some AMEs, in general a drop in the AME catalytic activity was observed in most of the cases. Analogues $\mathbf{4 d - f}$, which demonstrated the most potent antimicrobial activities, were also the poorest substrates for all of the tested AMEs.

Hence, bacterial strains containing the tested AMEs will have limited to no ability to inactivate analogues $\mathbf{4 d - f}$ through chemical modifications that are catalyzed by these enzymes. This is also true for the $S$-oxidized compounds $\mathbf{5 d - e}$ and $\mathbf{6 d - e}$, which behaved similarly to their non-oxidized counterparts $\mathbf{4 d - e}$ (Figure S46).

In conclusion, 18 novel 6"-thioether TOB analogues (4a-r) and $4 S$-oxidized compounds (5d-e and 6d-e) have been synthesized and screened for antibacterial activity. The $\mathrm{C}_{12^{-}}$, $\mathrm{C}_{14^{-}}$, and $\mathrm{C}_{16^{-}}$-linear chain analogues $\mathbf{4 d - f}$ demonstrated potent activity against bacterial strains with high levels of resistance to TOB. We found evidence that the most potent analogue $4 \mathbf{e}$ targets bacterial membranes and no longer targets the ribosome as does the parent drug. Hemolysis tests indicated that it is possible to improve the antibacterial activity while reducing the undesired hemolytic effect by altering the length of the aliphatic chain. Finally, thioethers $\mathbf{4 d - f}$ served as poor substrates for several AMEs, demonstrating that AMEs have a limited deactivating effect on these AG analogues. The results reported in this manuscript offer guidelines for the design of bacterial membrane targeting amphiphilic AGs.

\section{Supplementary Material}

Refer to Web version on PubMed Central for supplementary material.

\section{References}

[1]. a) Fridman M, Belakhov V, Yaron S, Baasov T. Org. Lett. 2003; 5:3575-3578. [PubMed: 14507176] b) Houghton JL, Green KD, Chen W, Garneau-Tsodikova S. Chembiochem. 2010; 11:880-902. [PubMed: 20397253] c) Wright GD, Berghuis AM, Mobashery S. Adv. Exp. Med. Biol. 1998; 456:27-69. [PubMed: 10549363]

[2]. a) Magnet S, Blanchard JS. Chem. Rev. 2005; 105:477-498. [PubMed: 15700953] b) MingeotLeclercq MP, Glupczynski Y, Tulkens PM. Antimicrob. Agents Chemother. 1999; 43:727-737. [PubMed: 10103173]

[3]. Kotra LP, Haddad J, Mobashery S. Antimicrob. Agents Chemother. 2000; 44:3249-3256. [PubMed: 11083623]

[4]. a) Ouberai M, El Garch F, Bussiere A, Riou M, Alsteens D, Lins L, Baussanne I, Dufrene YF, Brasseur R, Decout JL, Mingeot-Leclercq MP. Biochim. Biophys. Acta. 2011; 1808:1716-1727. [PubMed: 21291859] b) Bera S, Zhanel GG, Schweizer F. J. Med. Chem. 2010; 53:3626-3631. [PubMed: 20373816] c) Baussanne I, Bussiere A, Halder S, Ganem-Elbaz C, Ouberai M, Riou

Angew Chem Int Ed Engl. Author manuscript; available in PMC 2013 June 04. 
M, Paris JM, Ennifar E, Mingeot-Leclercq MP, Decout JL. J. Med. Chem. 2010; 53:119-127. [PubMed: 20000576] d) Hanessian S, Pachamuthu K, Szychowski J, Giguere A, Swayze EE, Migawa MT, Francois B, Kondo J, Westhof E. Bioorg. Med. Chem. Lett. 2010; 20:7097-7101. [PubMed: 20970332]

[5]. Epand RF, Savage PB, Epand RM. Biochim. Biophys. Acta. 2007; 1768:2500-2509. [PubMed: 17599802]

[6]. a) Findlay B, Zhanel GG, Schweizer F. Antimicrob. Agents Chemother. 2010; 54:4049-4058. [PubMed: 20696877] b) Giuliani A, Rinaldi AC. Cellular and molecular life sciences. 2011; 68:2255-2266. [PubMed: 21598022] c) Yin LM, Edwards MA, Li J, Yip CM, Deber CM. J. Biol. Chem. 2012; 287:7738-7745. [PubMed: 22253439]

[7]. a) Wang H, Tor Y. Bioorg. Med. Chem. Lett. 1998; 8:3665-3670. [PubMed: 9934492] b) Wang H, Tor Y. Angew. Chem. Int. Ed. Engl. 1998; 37:109-111.

[8]. a) Chen W, Biswas T, Porter VR, Tsodikov OV, Garneau-Tsodikova S. Proc. Natl. Acad. Sci. U S A. 2011; 108:9804-9808. [PubMed: 21628583] b) Green KD, Chen W, Garneau-Tsodikova S. ChemMedChem. 2012; 7:73-77. [PubMed: 21898832]

[9]. a) Wynalda MA, Hutzler JM, Koets MD, Podoll T, Wienkers LC. Drug. Metab. Dispos. 2003; 31:878-887. [PubMed: 12814964] b) Katopodis AG, Smith HA, May SW. J. Am. Chem. Soc. 1988; 110:897-899.

[10]. a) Hobbie SN, Kalapala SK, Akshay S, Bruell C, Schmidt S, Dabow S, Vasella A, Sander P, Bottger EC. Nucleic Acids Res. 2007; 35:6086-6093. [PubMed: 17766247] b) Sucheck SJ, Wong AL, Koeller KM, Boehr DD, Draker K-A, Sears P, Wright GD, Wong C-H. J. Am. Chem. Soc. 2000; 122:5230-5231.

[11]. Eldar A, Chary VK, Xenopoulos P, Fontes ME, Loson OC, Dworkin J, Piggot PJ, Elowitz MB. Nature. 2009; 460:510-514. [PubMed: 19578359]

[12]. Szychowski J, Kondo J, Zahr O, Auclair K, Westhof E, Hanessian S, Keillor JW. ChemMedChem. 2011; 6:1961-1966. [PubMed: 21905229]

[13]. a) Wolf E, Vassilev A, Makino Y, Sali A, Nakatani Y, Burley SK. Cell. 1998; 94:439-449. [PubMed: 9727487] b) Wybenga-Groot LE, Draker K, Wright GD, Berghuis AM. Structure. 1999; 7:497-507. [PubMed: 10378269] c) Sakon J, Liao HH, Kanikula AM, Benning MM, Rayment I, Holden HM. Biochemistry. 1993; 32:11977-11984. [PubMed: 8218273] d) Hon WC, McKay GA, Thompson PR, Sweet RM, Yang DS, Wright GD, Berghuis AM. Cell. 1997; 89:887-895. [PubMed: 9200607]

[14]. a) Green KD, Chen W, Garneau-Tsodikova S. Antimicrob. Agents Chemother. 2011; 55:32073213. [PubMed: 21537023] b) Porter VR, Green KD, Zolova OE, Houghton JL, GarneauTsodikova S. Biochem. Biophys. Re.s Commun. 2010; 403:85-90. 


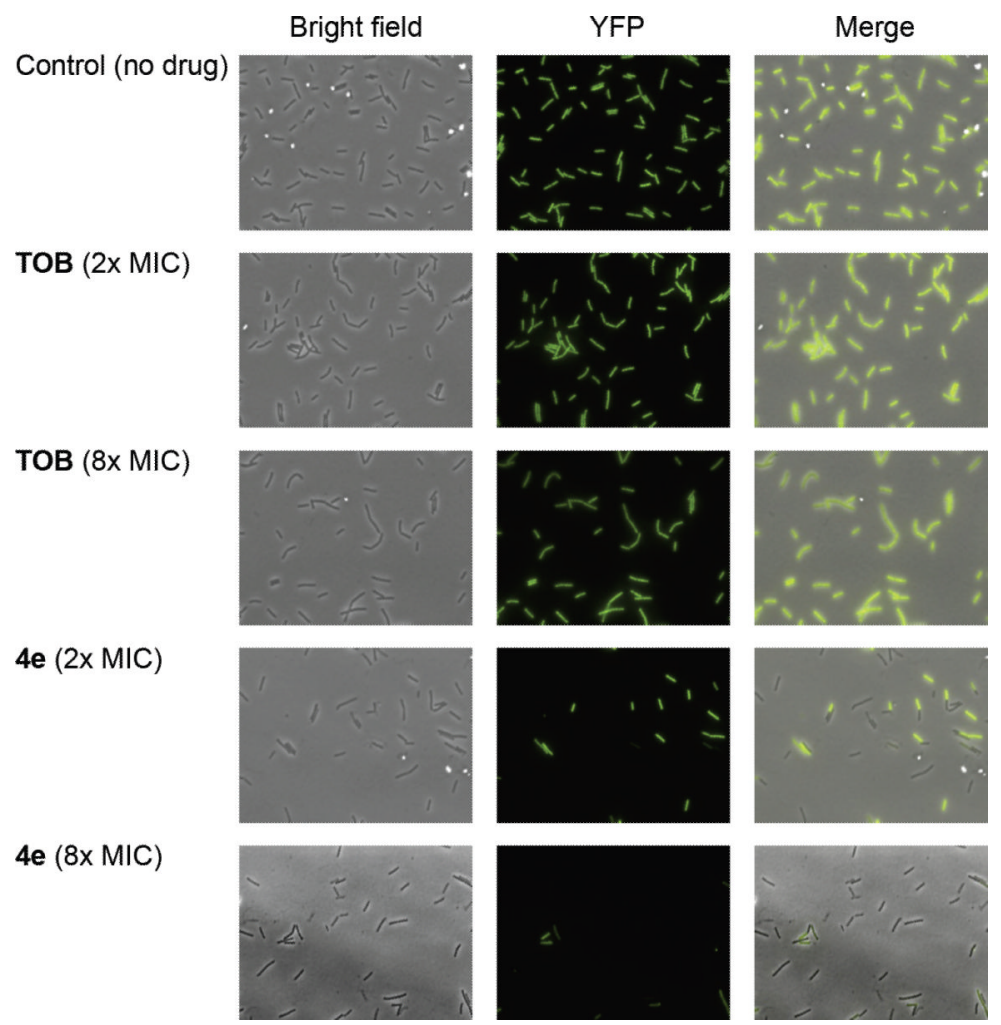

Figure 1.

Bright field and epi-fluorescence microscopy. B. subtilis (PY79) cells carrying YFP under an inducible IPTG promoter treated with TOB at $2.3 \mu \mathrm{g} / \mathrm{mL}(2 \times$ MIC) and $9.4 \mu \mathrm{g} / \mathrm{mL}(8 \times$ MIC) or with compound $4 \mathrm{e}$ at $4.7 \mu \mathrm{g} / \mathrm{mL}(2 \times$ MIC) and $18.8 \mu \mathrm{g} / \mathrm{mL}(8 \times$ MIC). 


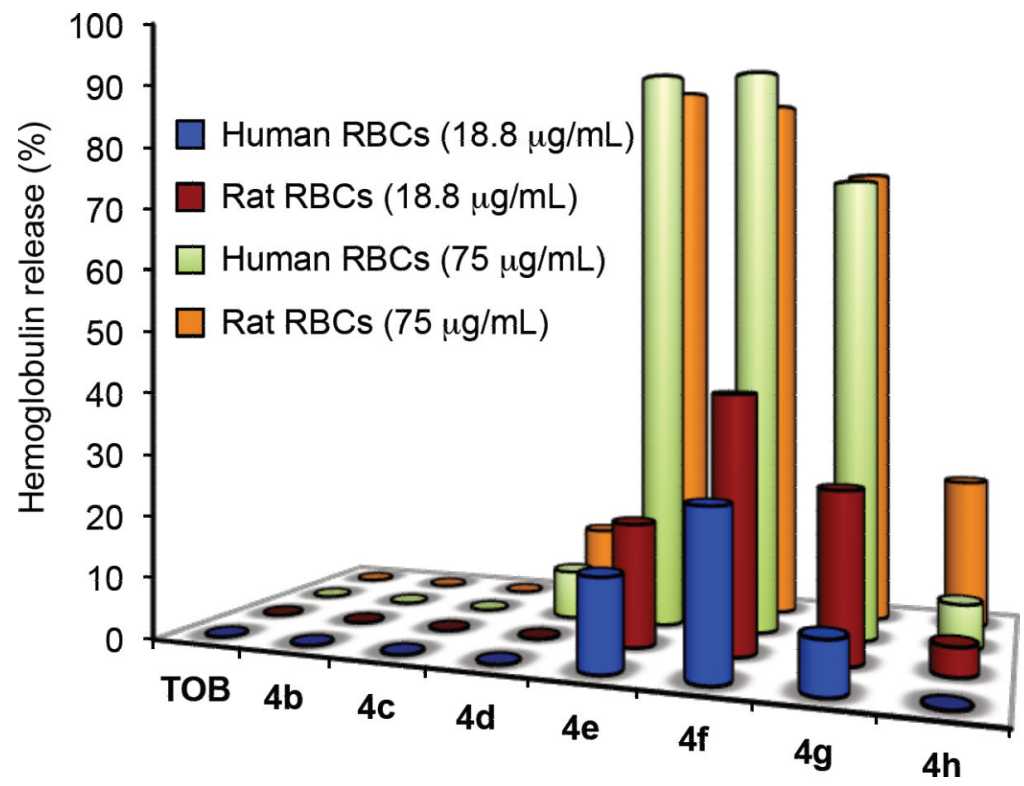

Figure 2.

Hemolysis tests. Human RBCs (blue " $18.8 \mu \mathrm{g} / \mathrm{mL}$ " and green " $75 \mu \mathrm{g} / \mathrm{mL}$ ") and rat RBCs (red " $18.8 \mu \mathrm{g} / \mathrm{mL}$ " and orange " $75 \mu \mathrm{g} / \mathrm{mL}$ ") were incubated with TOB or with analogues 4b-h at concentrations of $18.8 \mu \mathrm{g} / \mathrm{mL}$ or $75 \mu \mathrm{g} / \mathrm{mL}$ for $1 \mathrm{~h}$ at $37^{\circ} \mathrm{C}$. 


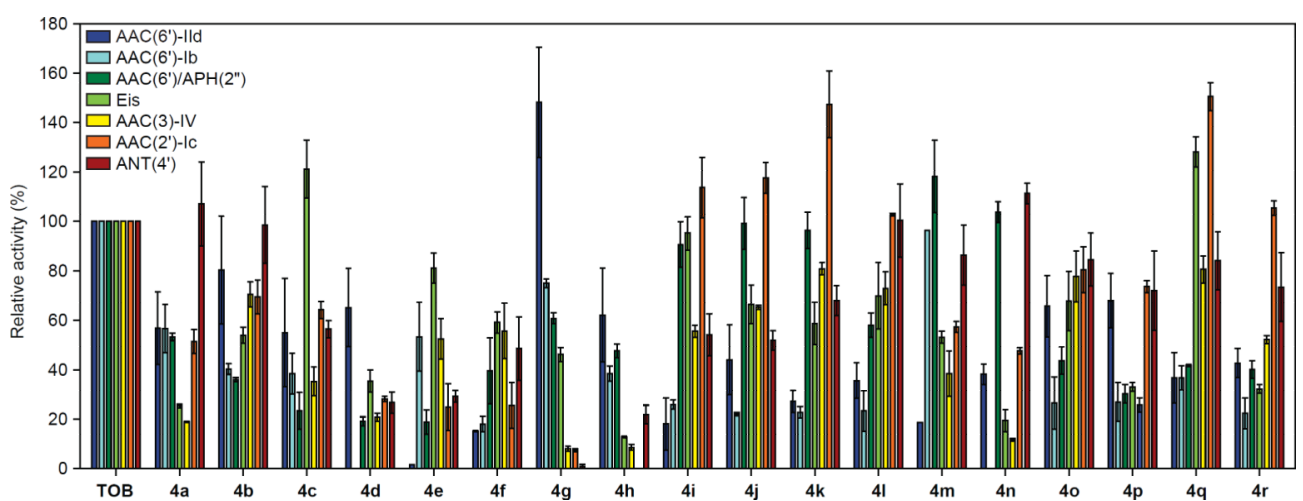

Figure 3.

Bar graph showing the relative initial rates of AME reactions with TOB and the 6"-thioether analogues 4a-r. Rates are normalized to TOB. AMEs tested include AAC(6')-IId (blue), $\mathrm{AAC}\left(6^{\prime}\right)-\mathrm{Ib}$ (cyan), AAC(6')/APH(2”) (dark green), Eis (light green), AAC(3)-IV (yellow), AAC(2')-Ic (orange), and ANT(4') (red). 


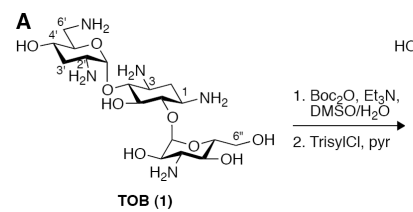

HO $\mathrm{S}_{\mathrm{O}}^{\mathrm{NHBOC}}$

$\mathrm{Sin}^{\mathrm{NHBOC}}$

NHBoc

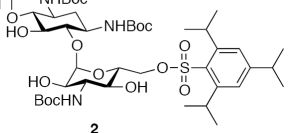

TOB (1)

$\mid \begin{aligned} & \mathrm{RSH}, \mathrm{Cs}_{2} \mathrm{CO}_{3}, \\ & \mathrm{DMF}\end{aligned}$

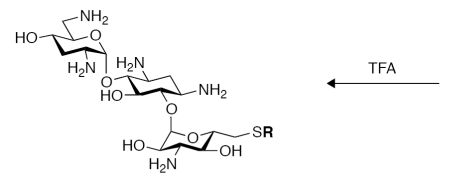

HO $-\sum_{\text {BocHN }}^{S_{0}^{N H B O C}}$

NHBOC
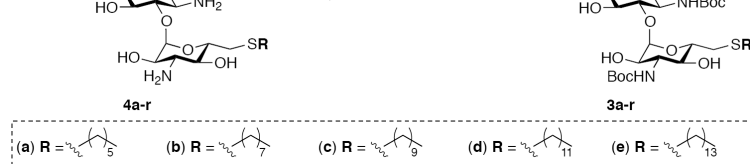

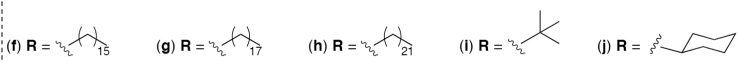
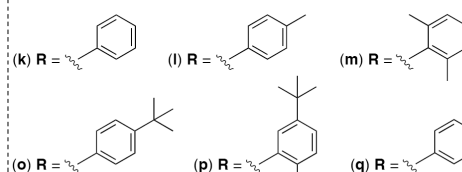

(n) $R=n_{2}$

B
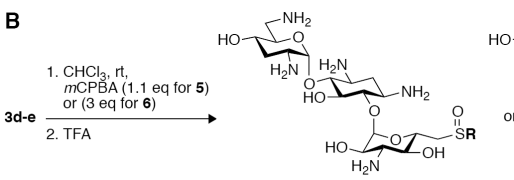

$\mathrm{SO}^{\mathrm{NH}_{2}}$



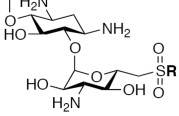

6d-e

\section{Scheme 1.}

A. Synthesis of 18 novel 6"-thioether TOB derivatives (4a-r). B. Oxidation of the thioether analogues 3d-e into the corresponding sulfoxides $\mathbf{5 d - e}$ and sulfones $\mathbf{6 d - e}$. 
